\title{
Anomalous aortic origin of a coronary artery (AAOCA) from the opposite sinus of Valsalva
}

\author{
Dominika M Zoltowska, ${ }^{1}$ Yashwant Agrawal, ${ }^{2}$ Guramrinder Singh Thind, \\ Jagadeesh K Kalavakunta ${ }^{1,3}$
}

'Department of Internal Medicine, Western Michigan University School of Medicine, Kalamazoo, Michigan, USA ${ }^{2}$ Internal Medicine and Pediatrics, Western Michigan University Homer Stryker School of Medicine, Kalamazoo, Michigan, USA

${ }^{3}$ Cardiology, Borgess Medical Center, Kalamazoo, Michigan, USA

Correspondence to Dr Dominika M Zoltowska dominika.zoltowska@med. wmich.edu

Accepted 2 May 2018

\section{DESCRIPTION}

A 77-year-old woman with multiple risk factors for coronary artery disease, was referred for left heart catheterisation after abnormal dobutamine stress test, revealing anterior and anterolateral hypokineses. Coronary angiogram revealed a large, dominant right coronary artery (figure 1A), originating from the right coronary cusp along with underdeveloped anomalous left coronary system. Left main artery was absent. Left anterior descending artery (LAD) was originating from right coronary cusp posteriorly (figure 1B), while the left circumflex artery (LCx) from the same cusp anteriorly (figure 1C). Probably the small calibre of the LAD and LCx might be the cause of abnormal stress echo findings. No significant obstructive disease was noted and the patient was

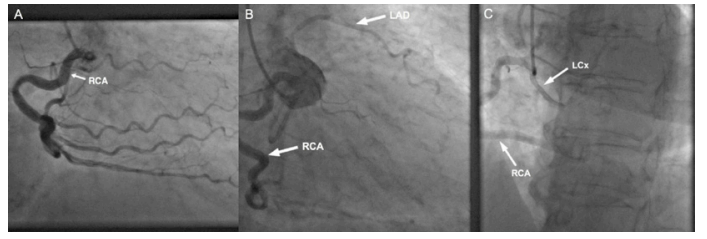

Figure 1 (A) LAO cranial view. Dominant large calibre right coronary artery (RCA). (B) RAO caudal view. Left anterior descending artery (LAD) originating from right coronary cusp posteriorly. (C) LAO caudal view. Left circumflex artery (LCX) originating from anterior aspect of right coronary sinus.

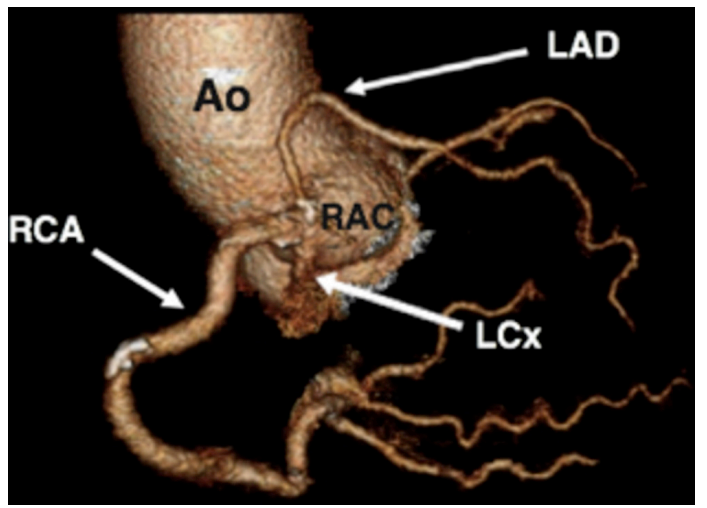

Figure 2 Three-dimensional CT of coronary arteries. Three coronary arteries originating from the same right aortic cusp. Ao, aorta; RAC, right aortic cusp; RCA, right coronary artery; LCX, left circumflex artery; LAD, left anterior descending artery.

\section{Learning points}

The utilisation of $\mathrm{CT}$ in establishing the anomalous coronary anatomy.

- The importance of recognition of the malignant course of anomalous arteries.

- Surgical treatment and close clinical follow-up of the patients with a left anomalous coronary artery originating from the right sinus of Valsalva.

qualified for medical treatment. Subsequent CT of the heart confirmed the anomalous coronary anatomy (figure 2).

Anomalous aortic origin of a coronary artery from the opposite sinus of Valsalva is a rare $(0.1 \%-0.3 \%),{ }^{1}$ but intensively investigated entity, associated with sudden cardiac death (SCD). The intramural course of anomalous left main artery between aorta and pulmonary artery is associated with the highest risk of SCD. The proposed mechanism of ischaemia comprises the obstruction of a flap-like orifice, usually during exertion. There are no established guidelines regarding the treatment. Nevertheless, based on recent data, surgery should be offered to all young patients with a left anomalous coronary artery originating from the right sinus of Valsalva. ${ }^{2}$

Contributors DMZ, YA, GST and JK were the physicians in charge of the patient throughout hospitalisation and follow-up. DMZ and JK were responsible for performing, diagnosing and discussing the imaging studies of the patient. DMZ prepared the manuscript draft, which was critically revised by YA, GST, and JK, and approved by all authors.

Funding The authors have not declared a specific grant for this research from any funding agency in the public, commercial or not-for-profit sectors.

Competing interests None declared.

Patient consent Obtained.

Provenance and peer review Not commissioned; externally peer reviewed.

(C) BMJ Publishing Group Ltd (unless otherwise stated in the text of the article) 2018. All rights reserved. No commercial use is permitted unless otherwise expressly granted.

\section{REFERENCES}

1 Yamanaka 0, Hobbs RE. Coronary artery anomalies in 126,595 patients undergoing coronary arteriography. Cathet Cardiovasc Diagn 1990;21:28-40

2 Mery CM, Lawrence SM, Krishnamurthy R, et al. Anomalous aortic origin of a coronary artery: toward a standardized approach. Semin Thorac Cardiovasc Surg 2014:26:110-22. 
Copyright 2018 BMJ Publishing Group. All rights reserved. For permission to reuse any of this content visit http://group.bmj.com/group/rights-licensing/permissions.

BMJ Case Report Fellows may re-use this article for personal use and teaching without any further permission.

Become a Fellow of BMJ Case Reports today and you can:

- Submit as many cases as you like

- Enjoy fast sympathetic peer review and rapid publication of accepted articles

Access all the published articles

- Re-use any of the published material for personal use and teaching without further permission

For information on Institutional Fellowships contact consortiasales@bmjgroup.com

Visit casereports.bmj.com for more articles like this and to become a Fellow 